Vol. 14 (2005): 277-292.

\title{
Does scale matter? Cost-effectiveness of agricultural nutrient abatement when target level varies
}

Antti Iho

Department of Economics and Management, PO Box 27, FI-00014 University of Helsinki, Finland, e-mail:antti.iho@helsinki.fi

\begin{abstract}
Agriculture is facing stringent requirements for nutrient loss reductions. These reductions should be done cost-effectively. For instance, the European Water Framework Directive (WFD) emphasizes cost-effectiveness in reaching good water status in European river basins by 2015. River Basin Management Plans specify the eventual reduction targets, which will differ between the basins. These differences have implications on cost-effectiveness assessments: changing the level of total abatement changes the relative shares of measures in the cost-effective allocation. In this paper we develop a model which determines the cost-effective allocation of three alternative measures to reduce phosphorus loss from fields. The model allows for comparisons with cost and reductions of all possible allocations. We show that, even for homogenous regions, the cost-effective allocation of measures is strongly dependent on the target level, and that using the allocation from one reduction level as a guideline for other levels violates cost-effectiveness seriously. On the grounds of these results we give recommendations for cost-effectiveness assessments in the context of the WFD.
\end{abstract}

Key words: cost-effectiveness, phosphorus abatement, buffer strips, wetlands, fertilizer use, Water Framework Directive, target setting

\section{Introduction}

Agri-environmental policy is typically driven by political target setting. For instance the Helsinki Convention requires a $50 \%$ reduction of nutrient loads to the Baltic Sea (HELCOM 1994). This affects Finnish water protection targets until 2005 with the goal of reducing the anthropogenic phosphorus load by $45 \%$, and nitrogen by $40 \%$, from the levels of the early 90s (Vesiensuojelun tavoitteet vuoteen 2005). Pressure is increasing to reduce agricultural phosphorus runoff, its contribution to anthropogenic phosphorus levels being 60\% (Finland's Natural Resources and the Environment 2002).

Finland's program for the protection of the Baltic Sea from the year 2002 calls for 20000 hectares of wetlands and 40000 hectares of buffer strips to be established. Together with agreements 
Iho, A. Cost-effectiveness of agricultural nutrient abatement when target level varies

for reduced use of fertilizers, controllable drainage systems and organic farming this should reduce loadings by about $40 \%$ in total phosphorus and nitrogen levels (Suomen Itämeren suojeluohjelma 2002).

The European Water Framework Directive (WFD) takes a different approach towards setting targets. It requires River Basin Management Plans to identify basin specific targets, baseline scenarios, gaps and schemes of measures. Even though the national goals and programs remain in effect, WFD differentiates regions with respect to reduction targets. Thus the eventual targets will be set on the basis of the needs of single basins only, and can hence be different even between fairly similar basins.

The importance of achieving environmental targets cost-effectively is commonly acknowledged. This requires identifying the effects of potential measures and the associated costs. There are significant differences in assessing efficiency nationwide compared to operations of a smaller scale. Simple calculations can show that heterogeneous agricultural regions have different cost-effective solutions to reach the same target (see e.g. Sharpley and Rekolainen 1997). Nationwide planning loses efficiency due to this heterogeneity of areas. More diversified planning, like that induced by WFD, avoids this problem to some extent. The question remains though, will there be major differences in cost-effective allocations, even between homogeneous regions, with different target levels?

Analysing efficiency of agricultural environmental policy is complicated. Ambient water quality is not directly linked to pollution loads from a basin. The observability of nutrient losses is limited and also impedes the creation of the right incentives for the economic agents (Segerson 1988, Fleming and Adams 1997). Uncertainty can be reduced by increasing spatial information on emissions (Xepapadeas 1995). Benefits gained from this are tempered by the costs incurred in gathering more information (Helfand and House 1995).

Assessing costs and effects of agricultural nutrient abatement is difficult. It requires simultaneous use of biological and economic models or data.
Vatn et al. (1999) provide a framework for interdisciplinary modelling, and an application for assessing cost-effectiveness of different strategies for reducing nitrogen and phosphorus losses. Their application uses deterministic and stochastic physical submodels to predict the physical and economic consequences of chosen actions. Their model, however, is primarily meant for analysing various policy scenarios, not for finding the costeffective combinations of policies.

Studies specific to the cost-effectiveness of agricultural nutrient reductions in the Baltic basin include, for instance, Byström (2000) on cost-effectiveness with or without the use of wetlands, Ollikainen and Honkatukia (2001) and Gren (2001) on cost-effectiveness with or without international coordination. Eloffson (1997) builds a spatial model of agricultural nitrogen reduction for the whole basin. She estimates cost functions of eleven measures to reduce nitrogen and presents costeffective solutions for different target levels.

Hart and Brady (2002) examine the issue of different target types in their study on efficiency of agricultural policies in reducing pollution of the Baltic Sea. Their focus is on regulator's optimal responses to three alternative ways of setting the target: the three variables being emissions, nutrient stock and ecosystem quality. Their approach includes various measures, with a focus on choice of crop, management practices, and the levels of fertilizer use. The efficient abatement solutions are combinations of these. They find that optimal strategy is strongly dependent on both the types and the levels of targets.

Brady (2003) introduces regional aspects and agricultural policy into a nitrogen abatement model. He defines a least-cost solution based on present levels of agricultural subsidies as second best and compares it with a least-cost solution based on the situation where subsidies are decoupled from production. The optimal solutions differed substantially in land use allocations, abatement intensity and total costs of abatement. Both Brady (2003) and Hart and Brady (2002) used mathematical programming models.

What has not been analysed, however, is how robust cost-effectiveness of an abatement alloca- 
Vol. 14 (2005): 277-292.

tion is inside one region, or between identical regions, with varying target levels. That is, how severely does application of abatement measures in uniform ratios affect the cost-effectiveness of abatement, given variation in abatement targets?

We use the River Basin approach of WFD to illustrate the idea. Suppose we have two (almost) identical basins, whose nutrient loads enter different waterbodies, and that these waterbodies differ in their sensitivity towards external phosphorus load. Further suppose that the baseline scenarios suggest that neither of the waterbodies reaches a good status by the year 2015, and therefore supplementary measures ${ }^{1}$ have to be introduced. Due to differences in their sensitivity towards phosphorus load, we can assume that the River Basin Plans (RBP) of the two basins will eventually set different targets on phosphorus abatement. WFD requires that cost-effectiveness of supplementary measures has to be assessed in RBPs.

To save money there might exist an incentive to generalize abatement plans. How much can the one basin benefit from cost-effectiveness assessments conducted for the other basin? Are there any dangers entailed in making the assessment for one basin and then adapting the same cost-effective scheme of measures to the other basin, but on a different scale? Can efficiency be violated? This paper aims at answering these questions.

In the present study we quantify the importance of correctly setting the target levels for nonpoint source phosphorus abatement. We consider a single type of phosphorus abatement target, that is set at different levels. We solve the cost-effective allocations of measures and analyse how the efficiency is affected when we use the allocations on a smaller scale. For this purpose we develop a static nonlinear mathematical programming model that generates cost-effective solutions for various target levels inside a region. The model is applied here to Yläne River Basin, in Southwest Finland, and considers 3 measures: reducing the use of

1 By supplementary measures we mean the abatement measures used on top of the measures included in the baseline scenario. phosphorus fertiliser (hereafter: P-fertiliser), creating buffer strips and creating wetlands.

The rest of the paper is organized as follows: Firstly we present the analytical model, secondly we introduce the numerical model and apply it to Yläne River Basin, thirdly we present the results, and finally, we discuss the results.

\section{The analytical model}

Cost-effectiveness equalizes marginal abatement costs from all sources of pollution for any target level (e.g. Baumol and Oates 1988). We can use this general result to illustrate the central idea of the paper. Measures to prevent and reduce agricultural nutrient loads vary, in terms of initial costs, effectiveness etc, resulting in nonidentical abatement and marginal abatement functions for different measures.

Figure 1 presents three arbitrarily chosen curvatures of marginal abatement cost functions ${ }^{2}$. Readers can think of these as: marginal abatement costs for wetlands, $M C_{w}$; fertilizer reductions for an unspecified crop, $M C_{P}$; and construction of buffer strips, $M C_{s}$.

In the graph we have depicted allocations of abatement measures that satisfy two different pollution constraints: high (") and low ( "). The horizontal axis denotes the level of abatement of each measure, under the two constraints. The vertical axis denotes the marginal abatement cost, and the shadow price associated with the pollution constraints. In the cost-effective solution for the higher pollution constraint the buffer strips reduce the pollution by $s^{\prime \prime}$, wetlands by $w^{\prime \prime}$, and fertilizer reduction by $P$ ". The overall level of abatement is a sum of these if we assume that measures are independent. The shadow cost of the constraint is $\lambda$ ".

The contribution of measures towards abatement differs radically between the two constraints.

\footnotetext{
2 The curvatures are chosen for illustrative purposes and thus do not represent the results of this paper.
} 


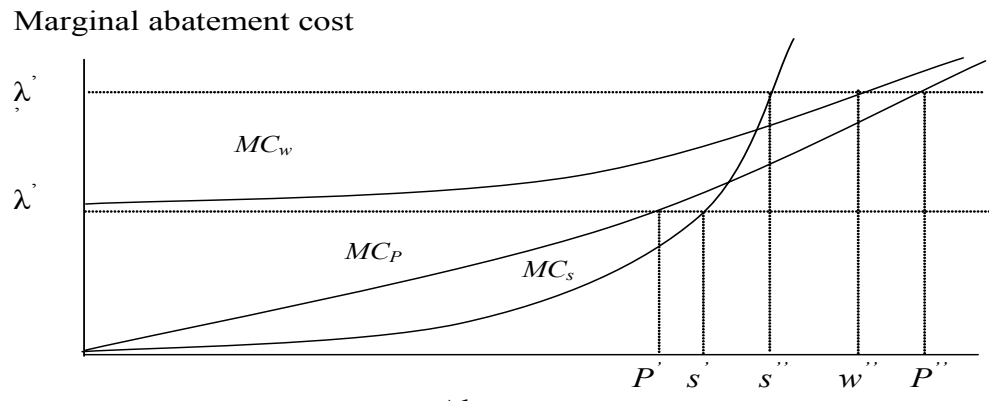

Abatement
Fig. 1. Uniqueness of cost-effective abatement allocations of three measures, at two different levels of total abatement. The curves $M C_{w}, M C_{P}$ and $M C_{s}$ depict illustrative marginal abatement cost curves for three different measures. $\lambda$ depicts the shadow cost of pollution constraint. Total abatement is the sum of individual abatement contributions.
For instance, cost-efficiency requires that for the lower pollution constraint we use no wetlands, and the buffer strips become the most important contributor to overall reduction. Hence using the contribution ratios of the higher constraint for the lower constraint would not yield a lowest cost allocation of abatement and vice versa. Our aim is to analyse how severely the conditions of cost-effectiveness are violated by linearly scaling cost-effective measure allocations for various levels of agricultural phosphorus abatement.

In our model we link costs due to both changes in agricultural production and introduction of phosphorus abatement measures, with their respective changes in phosphorus loss. We consider a single region which can be viewed as a representative farm. The quality of soil varies within the region and the land is allocated to different crops on the basis of these differences. This allocation is assumed to be fixed and we assume that a certain crop is always allocated to a certain soil type ${ }^{3}$. In addition to crop distribution, soil quality distribution mainly determines the phosphorus loss (hereafter referred to as P-loss). Social planner can combine three measures to reduce P-loss: phos-

3 This is a restrictive assumption. Several studies have shown that the crop allocation depends also strongly on economic variables: input and output prices, subsidies etc. (see e.g. Lichtenberg 2002, Lankoski and Ollikainen 2003). However, in view of our research questions, this assumption can be made without loss of generality. phorus application levels ${ }^{4}$ for various crops, buffer strip width and the size of a representative wetland. The abatement combination has to satisfy an exogenous constraint on total P-loss with the lowest possible cost.

We define the loss of total phosphorus from the region as:

$$
E=\sum_{i=1}^{n} e\left(\theta_{i}, P_{i}, w, s\right),
$$

where:

$\theta$ : a phosphorus status parameter for soil type $i=1 \ldots n$

$P_{i}$ : phosphorus application to a crop allocated to soil $i=1 \ldots n$

$w$ : area of wetlands (or a representative wetland)

$s$ : width of buffer strip.

Thus the total P-loss from the region is the sum of P-losses from all the region's soil types. The parameter $\theta$ captures two relevant aspects of soil quality: the crop yield potential and the P-loss potential. The representative wetland $(w)$ is common for the whole region, and the buffer strips $(s)$ of even width are constructed on locations suitable for them, independent of crop distribution. The model is thus very simple: it does not allow for crop rotation or targeting the buffer strips according to crop use. The abatement measures affect the

4 For illustration, we considered fertilizer reductions in Figure 1. From now on, we consider fertilizer application levels which, together with initial levels, define the fertilizer reductions as well. 
Vol. 14 (2005): 277-292.

average loss from the whole region, not individual losses separately. These simplifications can be done without compromising too much information relevant to our research questions. Obviously our assumptions make the exact values of abatement costs less precise. The effects of varying the scale of abatement, however, can be analysed with our model.

The costs include the opportunity cost of land at different levels of phosphorus fertilizer use, equal to net profit; and both establishment and maintenance costs of buffer strips and wetlands. The cost of an allocation $\{P, w, s\}$ under P-loss constraint, $E \leq \tilde{E}$ is

$$
C=\sum_{i=1}^{n}\left[\pi\left(\theta_{i}, P_{i}^{*}, w^{*}, s^{*}\right)-\pi\left(\theta_{i}, P_{i}, w, s\right)\right],
$$

where $P^{*}, w^{*}$ and $s^{*}$ denote the optimal choices of fertilizer input, acreage of wetland and buffer strip width in the absence of a constraint on P-loss. The cost is thus a sum of differences in profits over all soil types, i.e. between the private optimum and the allocation satisfying the pollution constraint. The profit from a soil type $i$ with fertilizer use $i$ is defined as:

$$
\pi_{i}=(1-w-s)\left[f\left(\theta_{i}, P_{i}\right) p_{i}-t_{i} P_{i}\right]-C C(w, s),
$$

where $p_{i}$ is the price of output of the respective crop, $t_{i}$ is the price of input (P-fertilizer), and $C C$ the initial, operational and maintenance costs of wetlands and buffer strips ${ }^{5}$. The detailed $C C$ function is presented with the application. The total acreage of land is scaled to 1 , hence the opportunity cost of wetlands and buffer strips is captured in $(1-w-s)$, where $(w+s)=[0,1]$.

The abatement cost is obtained by combining the cost of abatement, $C$, with the respective reduction in P-loss.

We make the following assumptions about cost functions:

$\partial C / \partial$ and $\partial C / \partial s>0$, and $\partial C / \partial P_{i}<0$ for all $i$

$\partial^{2} C / \partial w \partial w$ and $\partial^{2} C / \partial s \partial s=0$,

and $\partial^{2} C / \partial P_{i} \partial P_{i}>0$ for all $i$.

5 The $C C$ function has only $w$ and $s$ as its arguments since the opportunity cost is entirely captured in the first term of RHS.
Thus the costs of constructing acreage unit of a buffer strip or wetland are linear and increasing, and the cost function for fertilizer reduction is increasing and convex.

For the loss and abatement functions we assume:

$\partial E / \partial w$ and $\partial E / \partial s<0$,

$\partial^{2} E / \partial w \partial w$ and $\partial^{2} E / \partial s \partial s>0$

$\partial E / \partial P_{i}>0$ for all $i$

$\partial^{2} E / \partial P_{i} \partial P_{i}>0$ for all $i$.

Thus we assume P-loss to be decreasing and convex with respect to wetlands and buffer strips and increasing and convex with respect to fertilizer use.

The problem of the social planner is to select the cost-effective combination of wetlands, buffer strips and P-fertiliser subject to the constraint on P-loss. Formally, we have ${ }^{6}$ :

$$
\begin{gathered}
\max _{w, s, P}-C(\theta, w, s, P) \\
\text { s.t. } E(\theta, w, s, P)=\tilde{E}
\end{gathered}
$$

Our assumptions guarantee interior solutions. Solving a Lagrangian equation from (4) yields the first order conditions, which can be expressed as:

$$
\begin{aligned}
& \lambda=\frac{\partial C / \partial w}{\partial E / \partial w} \\
& \lambda=\frac{\partial C / \partial s}{\partial E / \partial s} \\
& \lambda=\frac{\partial C / \partial P_{i}}{\partial E / \partial P_{i}}, \text { for all } i=1 \ldots n \\
& E(\theta, w, s, P)=\tilde{E}
\end{aligned}
$$

Conditions $(5 a-5 c)$ require that the efforts of each abatement measure are increased up to the point where marginal abatement costs (marginal costs relative to marginal reduction) are equal for all abatement measures. Finally, condition (5d) guarantees that the overall reduction target is met. The shadow cost of the P-loss constraint is equal to $\lambda$, which is increasing in target reduction.

\footnotetext{
6 Now, for notational simplicity, $\theta$ and $P$ are vectors, as in $5 \mathrm{~d}$.
} 
We can solve (4) with a mathematical programming model. In the following, we present this numerical model, and apply it to a case study.

\section{Numerical model and its application to the Yläne Basin}

A key assumption in our model is that abatement costs are additively separable and abatement measures are independent ${ }^{7}$. Hence, the effect on abatement of a buffer strip (wetlands) is presumed not to depend on the level of fertilizer use or the construction of wetlands (buffer strips). To justify this assumption, note that buffer strips and wetlands reduce mainly particulate phosphorus from runoff. Even though not explicitly modeled in the present study, the effects of changes in P-fertilizer use on P-loss take place via long run changes in soil phosphorus level. The loss of particulate phosphorus in runoff is quite insensitive to short term changes in fertilizer use (Ekholm et al. 2005) ${ }^{8}$. The combined effects of wetlands and buffer strips are not analysed in our model. If they both affect the same runoff, the interdependencies are obvious. We will discuss later the possible implications of taking these into account.

We apply the model using actual data from a sub-basin of the Yläne Basin, Southwest Finland. The calibrations and simplifications in the case study are based on land use allocations used by Palva et al. (2001) and crop use allocations from data provided by the ministry of Agriculture and Forestry, reported in Iho (2004). These are presented shortly at the end of the respective sections.

\footnotetext{
7 For more detailed technical description of the model, see Iho (2004)

8 One can think that in this model fertiliser reductions affect the leaching of (dissolved) phosphorus by slowly altering soil phosphorus status, whereas buffer strips and wetlands affect mainly the particulate phosphorus in the runoff. Explicit modeling would require dynamic analysis.
}

\section{The crop yield function}

In Finland the short and intensive growing season and strong binding of phosphorus into soil makes fertilizing a long term project. The phosphorous uptake occurs mainly from the plant-available phosphorus fraction of the soil phosphorus. The purpose of fertilizing is predominately to maintain this fraction (e.g. Saarela and Saarela 1999, Saarela et al. 2003). To incorporate the long term character of fertiliser use into a static model, we postulate the production function as follows.

In our case study we assume $\theta$ to be captured in the soil test phosphorus (STP). The crop allocation is made according to this and by looking at the actual allocation we can find justifications for assumptions on values of $\theta$. In the Yläne Basin over $90 \%$ of farm land is allocated to grain and grass, and approximately $2 \%$ to potatoes. Less than $1 \%$ is allocated to sugar beet, $5 \%$ to oilseeds, and $2 \%$ to peas.

We incorporate these features in our model by assuming that all the soil has either high or low $\theta$, and potatoes are allocated to high $\theta$ soils, barley to low $\theta$ soils. The allocation to barley is assumed to be $95 \%$. In this way, we incorporate the differences in soil quality in the model, while keeping it as simple as possible. We set the high $\theta$ to correspond to a STP value of 25 and the low $\theta$ to 13.4. Together with the chosen soil quality allocation, the average STP value will be the same as the actual values in the Yläne Basin as reported in Palva et al. (2001).

The crop yield function $f$ is constructed of two components ${ }^{9}$. The first one, $F$, is sensitive to the

\footnotetext{
9 Dividing crop yield function into two components where one is constant enables static modeling of growth in response to P-fertiliser. The same approach has been used by for instance Myyrä and Pietola (2005). In our model, the correct level of crop yield is of importance in defining the opportunity cost of land. The marginal effect of phosphorus fertilising (based on long term field experiments by Saarela et al. 1995 and 2003) defines the marginal costs of phosphorus reduction, which in turn defines the marginal abatement costs.
} 
Vol. 14 (2005): 277-292.

use of $\mathrm{P}$-fertilizer, and the second, $A$, is constant for each crop.

$$
f_{i}=F_{i}+A_{i}
$$

where $i$ is either potatoes or barley.

For the first component, we choose the yield response function of Saarela et al. $(1995)^{10}$ :

$$
\begin{aligned}
F_{i}= & y_{e} c_{i} P_{i}\left(-0.132 P_{i}+12.4\right)+ \\
& \left(24-0.367 \theta_{i}\right) \sqrt{P_{i}}+6.97,
\end{aligned}
$$

where $\theta(=S T P)=$ soil phosphorus, $y_{e}=$ experimental year and $c=$ crop parameter. The only choice variable in (7) is $P$. The crop parameters $c$ are 2 for potato and 1.05 for barely (Saarela et al. 1995) and the experimental year is fixed to 6 (the experimental periods of Saarela et al. (1995) were, on average, about 12 years each).

In equation (2) we define costs as differences between privately optimal allocations and allocations satisfying the P-loss constraint. In the application, we use fertilising levels adopted from Palva et al. (2001) as optimal levels, and the reductions are conducted from these at 1 kilogram per hectare intervals. These levels are set at $15 \mathrm{~kg} \mathrm{ha}^{-1}$ for barley and $45 \mathrm{~kg} \mathrm{ha}^{-1}$ for potatoes, and will be later referred to as the original levels of fertilizing ${ }^{11}$.

The constant component of the crop yield function is determined by (7), and by actual crop yield data for the Yläne region, i.e. the left-hand side of equation (6):

$$
A_{i}=f_{i}^{*}-F\left(P_{i}^{*}, \theta_{i}, y_{e}, c_{i}\right)
$$

10 The yield function having only phosphorus use as a choice variable is unsatisfactory: P-fertiliser is usually given in a fixed proportion with other nutrients. We ignore the cost of these by taking into the fertilizer cost only the proportion of $\mathrm{P}$ in the fertilizer mix.

${ }^{11}$ This assumption has weaknesses: the original level is influenced by subsidies. Also the rates are based on reported levels, and are thus subject to errors, both intended and unintended. But even though this affects the order of magnitude, the influence on our research question is not substantial. Under our assumptions, and with our model that does not account for the use of other inputs, the privately optimal fertilizer levels would be $39 \mathrm{~kg} \mathrm{ha}^{-1}$ for barley and $51 \mathrm{~kg} \mathrm{ha}^{-1}$ for potatoes. where $f^{*}$ is the average crop yield 1994-1999 and $P^{*}$ is the respective fertilizer level, as reported in Palva et al. (2001). Since (8) is determined by a fixed level of fertilisation, it is constant for both crops. With these levels, assumed STP values, and the crop yield levels reported in Palva et al (2001) we find the constant crop yield for potato to be $21,513 \mathrm{~kg} \mathrm{ha}^{-1}$ and for barley $3,728 \mathrm{~kg} \mathrm{ha}^{-1}$.

We assume that the average price is $€ 0.114 \mathrm{~kg}^{-1}$ for potato and $€ 0.125 \mathrm{~kg}^{-1}$ for barley ${ }^{12}$. For potatoes the price of fertilizer is $€ 0.46 \mathrm{~kg}^{-1}$ (P-ratio $3: 31$ ), and for barley $€ 0.32 \mathrm{~kg}^{-1}$ (P-ratio of 2:29).

\section{P-loss and abatement functions}

Among factors contributing to P-loss from agricultural land are: the level of easily soluble $\mathrm{P}$ in the soil, the type of fertilizer used, the methods of spreading, the soil type, the slope of the field, the crop used, and rainfall as en exogenous factor etc. (Sharpley 1995, Pote et al. 1996, Ylivainio 2002, Palva et al. 2001, Ekholm 1998). Our model directly includes only fertilizer use as a choice variable. The phosphorus status is accommodated indirectly as most of the P-loss is determined by $\theta$.

The phosphorus used for fertilising affects the P-loss mainly by steering the dynamics of soil phosphorus (McDowell and Sharpley 2001, YliHalla et al. 2002, Ekholm 2005). Given the exogenous variables, rainfall in particular, most of the loss occurs on the basis of soil properties that are constant in the short run. We can capture this again by separating the P-loss into a constant share, and a share that varies according to fertiliser use. The soils with high $\theta$ have higher constant values for P-loss than soils with low $\theta$. For the application, we assume that $5 \%$ of loss is determined by P-fer-

${ }^{12} \mathrm{We}$ assume that, on average, due to differences in eventual crop quality, $75 \%$ of the crop yield of both crops is sold at a higher price (€0.14 $\mathrm{kg}^{-1}$ for potatoes and $€ 0.131 \mathrm{~kg}^{-1}$ for barley) and $25 \%$ at a lower price (€0.034 $\mathrm{kg}^{-1}$ and $€ 0.108 \mathrm{~kg}^{-1}$ ). An individual farmer does not know how large a fraction of his/her crop yield can eventually be sold at a higher price. 
Iho, A. Cost-effectiveness of agricultural nutrient abatement when target level varies

tilizer use, $95 \%$ by the constant term at the original level of fertilisation.

Following an unpublished work by Granlund et al., we assume the P-loss from land growing barley to be $1.11 \mathrm{~kg} \mathrm{ha}^{-1} \mathrm{a}^{-1}$. We calibrate the actual reported total P-loss by Kuusela and Savola (2000) to match the loss induced by our assumed land-use allocations, and hence assume the P-loss from land growing potato to be $3.33 \mathrm{~kg} \mathrm{ha}^{-1} \mathrm{a}^{-1}$. Further, the contribution of fertilizer use at the original level is assumed to be $5 \%$ of the total P-loss ${ }^{13}$. With these assumptions the constants of P-loss are $1.04 \mathrm{~kg} \mathrm{ha}$ ${ }^{1} \mathrm{a}^{-1}$ and $3.16 \mathrm{~kg} \mathrm{ha}^{-1} \mathrm{a}^{-1}$. Making such a significant assumption about the P-loss coefficient is done mainly to enable us to conduct the analysis with two crops that are different in terms of their crop yield and P-loss characteristics.

\section{Buffer strips}

Buffer strips are used at field edges susceptible to erosion. We create a coefficient, $s$, which denotes the fraction of cultivated land suitable for buffer strips. Another coefficient, $k$, tells how much more intense the runoff is from these parts of the field.

The buffer strip's phosphorus abatement as a function of strip width takes the form:

$$
r b(m)=1-((s k) /(s k+(1-s))) * m^{\alpha},
$$

where $m$ is the width of the strip in hundreds of meters. The ratio $[0,1]$, given by the dependent variable, $r b$, is of the share of P-loss not removed by the strip. Equation (9) is based on the results of Uusi-Kämppä and Kilpinen (2000) and assumptions on the characteristics of buffer strip abatement ${ }^{14}$. According to Uusi-Kämppä and Kilpinen

\footnotetext{
${ }^{13}$ The 5\% share is the only part of the P-loss that can be reduced by fertilizer use reductions.

${ }^{14}$ We use buffer strip width as a choice variable. The function is postulated from Uusi-Kämppä and Kilpinen (2000), and is not presented elsewhere as such. For instance Vought et al. (1994) estimate abatement functions with width as a choice variable. We know, however, that the range of reported buffer strip abatement functions in various studies is very large, and all available functions
}

(2000) a buffer strip of 10 meters width removes $30-40 \%$ of the total phosphorus (TP) surface runoff. Approximately, an equal amount is lost in drainage, where the buffer strips have no effect (Uusi-Kämppä and Kilpinen 2000). Thus we assume that a $10 \mathrm{~m}$ wide buffer strip removes $17.5 \%$ of the TP runoff originating from the field. We also assume concavity of the abatement function with diminishing marginal abatement. We hence calibrate $\alpha$ to be 0.76 .

Based on buffer strip plans for the region we assumed that the field acreage from which the runoff can be reduced by buffer strips is $25 \%$ of the total field acreage ${ }^{15}$, hence $s$ is attributed the value 0.25 . The runoff is assumed to be three times higher from those parts of the field considered suitable for buffer strips; hence the parameter $k=3$. For the sensitivity analysis we vary, among other things, both the above mentioned values.

\section{Wetlands}

We postulate the abatement function for wetlands from the phosphorus reduction function of Puustinen et al. (2001):

$$
W(r)=13.1 r+0.01,
$$

where $r$ is the effective size of the wetland, divided by the acreage of the wetland catchment and $W$ denotes $T P$ reduction as a percentage. Obviously, a linear function has its weaknesses: after the relative size of $7.6 \%$ all the phosphorus is removed.

We constrain (10) by assuming the maximum TP abatement to be $75 \%$, in line with Reinhardt et al. (2005). We further assume this reduction to be achieved with the relative size of $10 \%$ and a logarithmic abatement function. By fitting these with the original values from Puustinen we have:

are hence very uncertain (Dosskey 2002). Therefore the tailored buffer strip abatement function based on UusiKämppä and Kilpinen (2000) was considered suitable for our purposes.

${ }^{15}$ Anni Karhunen. 1.7.2003. A written note. 
Vol. 14 (2005): 277-292.

$$
w(r)=25.1 \ln r+20.4
$$

which is a concave function.

As with buffer strips we assume that the acreage of wetland bound runoff is smaller than the whole field area. So the ratio of P-loss not removed by a wetland is:

$$
\begin{aligned}
& r w(r)= \\
& 1-\left[s s^{*}(25.1 \ln r+20.4)+(1-s s)\right] / 100,
\end{aligned}
$$

where ss denotes the fraction of the field acreage through which the runoff flows to the potential wetland $^{16}$. We assume this to be 0.15 , and later analyse the implications of the choice.

\section{Initial, operation and maintenance cost function}

All cost functions are implicitly defined by equation (2) as reductions in profit due to abatement decisions. We now define the explicit costs of constructing a wetland or a buffer strip in equation (3). Costs of fertilizer reduction are entirely captured in equation (2) and the production function (6).

The control cost function for buffer strips and constructed wetlands consist of initial costs (divided by the duration), yearly operation and maintenance costs and the opportunity cost of land. The function is:

$$
C C(w, s)=w(1458+59)+s(9+25),
$$

where the first term of each sum is the initial cost per hectare divided by 15 years, and the second term is the annual operations and maintenance

\footnotetext{
${ }^{16}$ Using the acreage as a choice variable is dubious. For instance Reinhardt et al. (2005) state that the most important factor affecting phosphorus retention in wetlands is the minimum water residence time: most of the phosphorus loss occurs during few high discharge events and the average retention capacity is not important (see also Sharpley and Rekolainen 1997). On the other hand, it is the relative size of a wetland that determines indirectly the water residence time. Better modeling of wetland retention would yield more realistic results.
}

cost. ${ }^{17}$ The costs of wetlands is adopted from Puustinen et al. (2001) and of buffer strips from Maatalouden ympäristöohjelma 1995-1999:n taloudellinen analyysi (1999), and Maa- ja metsätalousministeriö (2002).

\section{Results}

We first solved the model for seven different constraint levels, to see how the cost-effective combination of measures evolved in response to changing constraint. This way we were able to highlight how the relative abatement contribution $\operatorname{ratios}^{18}$ change with total abatement. These features are presented in Figure 2.

We then analyse how the conditions for costeffectiveness are violated if we use the cost-effective abatement contribution ratios of higher total abatement for lower total abatement levels. This is presented in Figure 3.

In general, the results indicated that the average unit cost of abatement was rising as the reduction target tightened, and hence the marginal abatement costs were rising, as predicted. The results also showed that the cost-effective allocations for all but the lowest total abatement level were combinations of all three measures, hence all measures were used after a certain level. The absolute amounts of abatement of all measures were rising up to $35 \%$ total abatement, i.e. as the target level rose, all measures were used more intensively. The relative shares on total abatement, however, changed substantially along the way.

\footnotetext{
${ }^{17}$ We do not discount costs, which naturally affects the values of cost functions. In sensitivity analysis we, however, varied the weights of abatement contributions and noticed that this has no significant effect on scale issues even though it has on optimal allocations.

${ }^{18}$ By abatement contribution ratio we mean the ratio of individual abatement measures on total abatement. For instance if wetlands would contribute to abatement of $5 \mathrm{~kg}$, buffer strips to $3 \mathrm{~kg}$, and fertiliser reductions to $7 \mathrm{~kg}$ of phosphorus, the total abatement would be $15 \mathrm{~kg}$, and the abatement contribution ratio would be 5:3:7.
} 
relative contribution

of measures

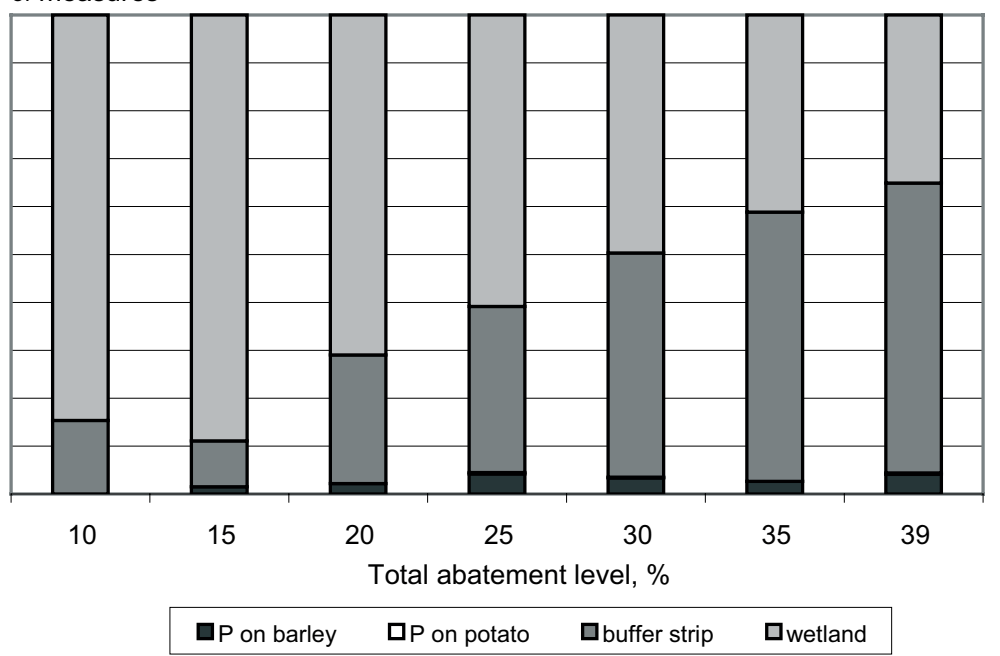

Fig. 2. The relative abatement contributions of each measure on different cost-effective total abatement levels. For instance the first bar shows that wetland contributes to a $10 \%$ total abatement by approximately $85 \%$ and buffer strips by $15 \%$.
Figure 2 presents the relative abatement contribution ratios of the measures for seven different total abatement levels. The ratios (see footnote 15 for definition) illustrate how the relative share of each measure in total abatement develops as the target level changes.

From Figure 2, the relative contributions of individual measures differ substantially under different reduction targets. Wetlands contribute to a significantly larger part of total abatement under low levels of abatement, whereas buffer strips contribute more heavily with higher target levels. The contribution to abatement of reducing fertilizer use is zero for the lowest target level and also remains relatively low at higher levels ${ }^{19}$. Recall that Figure 2 does not depict the values of absolute abatement of the measures. The change in relative contribu-

\footnotetext{
${ }^{19}$ If we had considered the theoretical private optimum as the initial level of fertilizer use (see footnote 8), the contribution of fertilizer reduction on total abatement would have been strictly positive from the first units of reduction. In the private optimum, the marginal cost of fertilizer equalizes its marginal benefit, hence, the marginal cost of fertilizer use reduction at that point is zero. Instead, we start with fertilizer levels that are already below the private optimum.
}

tions thus originates from differences in (marginal) abatement cost functions, similar to our illustrative example in Figure 1.

We see that all abatement contribution ratios are unique. More precisely, cost-effective abatement contribution ratios sustain cost-effectiveness only at their own total abatement levels. In the following, we will try to quantify this feature.

In Figure 3 we illustrate differences in average unit costs of abatement, due to using contribution ratios of higher total abatement for a $10 \%$ reduction. The examination is constructed as follows. The baseline unit cost is that of cost-effective 10\% abatement on TP. We compare this with unit costs of six alternative measure allocations, each resulting in the same, $10 \%$ abatement. The first alternative allocation uses the abatement contribution ratio of $15 \%$ cost-effective abatement, and scales all measures evenly downwards to sustain a $10 \%$ abatement. The difference in the unit costs is depicted on the vertical axis. The next allocation uses $20 \%$ cost-effective abatement, maintains the contribution ratio to reduce $10 \%$, and compares the unit costs. This is done until $39 \%$ abatement. In Figure 3 we thus do not compare unit costs of rising total abatement - all allocations yield the same total abatement. 
Vol. 14 (2005): 277-292.

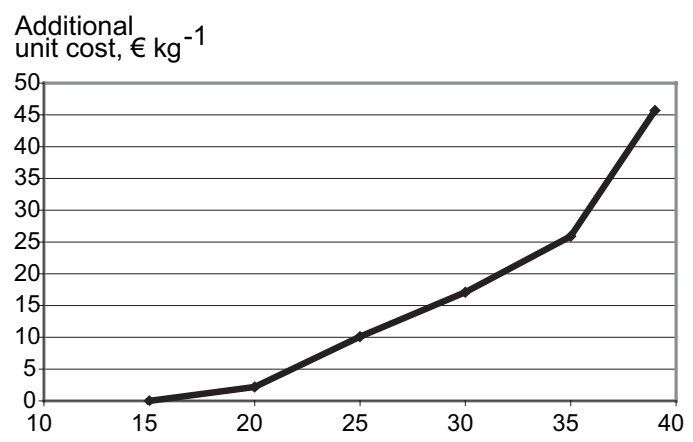

The rate of abatement the contribution ratio is adopted, \%

Fig. 3. The additional unit cost for a $10 \%$ total abatement, executed with different contribution ratios. The horizontal axis denotes the level of total abatement from which the contribution ratio is adopted. The vertical axis denotes how much higher the unit costs of $10 \%$ total abatement are than under the cost-effective ratio for a $10 \%$ reduction. The unit cost of a cost-effective $10 \%$ reduction is $€ 49$ $\mathrm{kg}^{-1}$. All points thus refer to a $10 \%$ total abatement.

From the graph we see that the difference in unit costs rises surprisingly rapidly. For instance, the average unit cost of reducing $10 \%$ of the phosphorus load, with a measure contribution ratio taken from $30 \%$ cost-effective abatement, is $€ 66$ $\mathrm{kg}^{-1}, 35 \%$ higher than the unit cost of cost-effective $10 \%$ abatement ( $€ 49 \mathrm{~kg}^{-1}$ ).

Again, it is important to note that the rising graph in Figure 3 does not represent rising unit costs of higher abatement levels. All points in the graph contribute towards approximately $10 \%$ abatement ${ }^{20}$. Unit costs do naturally rise with abatement levels, but much faster than in the graph (for instance, the average unit cost of $30 \%$ reduction is $\left.€ 120 \mathrm{~kg}^{-1}\right)$. The graph thus shows that it is very costly to apply abatement contribution ratios that are cost-effective at a unique level of total abatement, to any other total abatement level.

\footnotetext{
${ }^{20}$ In Figure 2 the comparison was done for different total abatement levels.
}

\section{Sensitivity analysis}

For the sensitivity analysis we varied input and output prices, land allocation changes, parameter values for crop yield and P-loss functions, and phosphorus abatement cost functions for wetlands and buffer strips (i.e. the parameters of initial, operations and maintenance cost, abatement and yield functions). We tried to find variations that would affect the relative abatement contribution ratios, and cost structure of measures. Some of the surprisingly rapid rising unit cost differences (see Figure 3) could be explained by the fact that the abatement contribution of wetlands is relatively high. Our model assumes a single wetland for the whole basin, with only its size as a choice variable. It provides specifically effective abatement at the lowest levels of total abatement, even though its initial costs are high. To see whether we observe similar unit cost differences with a smaller abatement role for wetlands, we consider a situation where the ratio of wetland abatement is significantly smaller at all levels of total abatement.

Simultaneously weakening the phosphorus abatement of the wetland, and increasing the contribution of fertilizer application to the P-loss caused a shift in phosphorus abatement from high initial cost wetlands towards lower initial costs (fertiliser reductions and the use of buffer strips). Recall that the maximum contribution of this years fertilizing on P-loss was originally set at $5 \%$. We increased this to $10 \%$ and lowered the maximum phosphorus abatement of wetlands to $50 \%$ (originally $75 \%)^{21}$. This would presumably change the cost-effective abatement contribution ratios, but to what extent?

The same basic results still hold: the cost-effective solutions were combinations of all measures, the intensity of all measures rose as the target tightened, and the cost-effective contribution ratios are unique for all levels of total abatement.

\footnotetext{
${ }^{21}$ Lowering the maximum abatement affects the whole range of wetland abatement cost function. The new function is also logarithmic and approaches the maximum abatement level smoothly.
} 
relative contribution

of measures

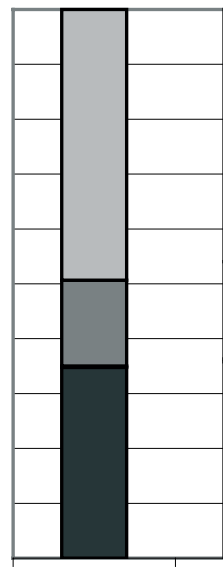

10

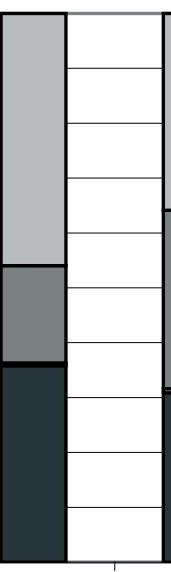

15

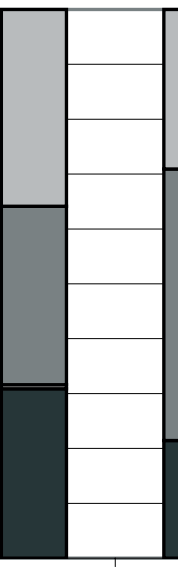

20

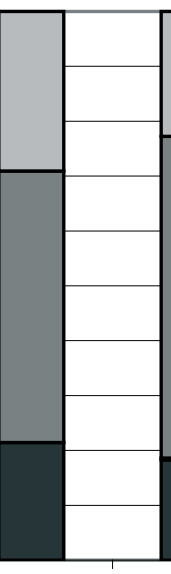

25

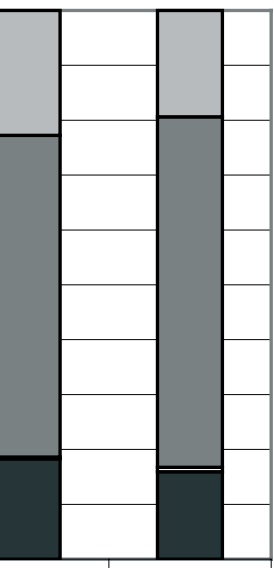

30
35
Total abatement level, \%

\begin{tabular}{|c|c|c|c|}
\hline$\square \mathrm{P}$ on barley & $\square \mathrm{P}$ on potato & $\square$ buffer strip & $\square$ wetland \\
\hline
\end{tabular}

Fig. 4. The relative abatement contributions of each measure when parameters of abatement cost functions are varied. The variations have changed the relative weights of measures, but not the effect of changing contribution ratios along with the total abatement level.
We examine the relative shares in a same manner as we did earlier in Figure 2. Figure 4 depicts the abatement contribution ratios in the new situation.

We see that the relative contributions of measures towards phosphorus abatement change from the original situation. We also see that the uniqueness of abatement contribution ratios remains. This consolidates the feature that contribution ratios can be cost-effective only at a unique level of total abatement.

Presumably however, there are quantitative changes due to greater use of measures with lower initial costs. These changes are presented in Figure 5 , which depicts the unit cost difference in a similar fashion to that of Figure 3.

In this case the cost-effective $10 \%$ phosphorus abatement has an average unit cost of $€ 71 \mathrm{~kg}^{-1}$. Applying the cost-effective ratio obtained for $30 \%$ phosphorus abatement to a $10 \%$ reduction target, raises the unit cost (of $10 \%$ abatement) by $€ 24$ $\mathrm{kg}^{-1}$, more than $30 \%$. Hence, even though the numeric values are different, the percentage variations seem to be very small.

An interesting question is the importance of the direction of scaling, i.e. whether we use the

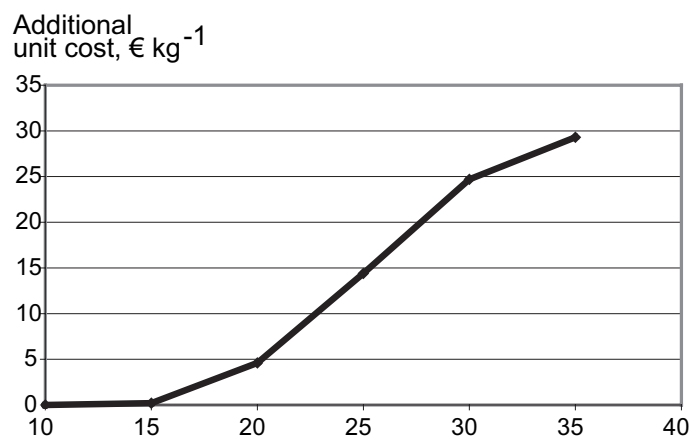

The rate of abatement the contribution ratio is adopted, \%

Fig. 5. The additional unit cost for a $10 \%$ total abatement with the respective parameter variation as in Figure 4. On vertical axis, note the different scale from Figure 3. The unit cost of a cost-effective $10 \%$ reduction is now $€ 71$ $\mathrm{kg}^{-1}$.

contribution ratio from a high total abatement level, and apply it to lower levels or vice versa. Since the cost-effective contribution ratios are unique for each total abatement level, there are costs incurred from scaling up as well. In our model, however, 
Vol. 14 (2005): 277-292.

the abatement measure used most for the $10 \%$ abatement (wetlands) has a maximum abatement capacity of $75 \%$. Scaling up would then mean substantial costs without respective increase in abatement, since we would have to increase the size of a wetland and incur costs, without gaining any increase in total abatement. In the context of WFD, however, scaling up might be an equally relevant issue.

In our paper the costs of measures were not discounted, an important consideration affecting the viability of measures with high initial costs (wetlands) compared to those with low initial costs (buffer strips and fertilizer reduction). The analysis above, however, suggests that changes in relative favourability of measures would not affect the general results of this study, namely the adverse effects from making linear transformations of policy recommendations obtained from nonlinear models.

\section{Discussion}

This paper shows that there is a potential caveat to policy recommendations on the basis of cost-effectiveness analysis. If we fix the ratio of abatement measures to a level that is cost-effective at a particular total abatement level, and then apply the ratio to other levels. The constraint, and hence the target level of abatement, strongly affects the relative favourability of abatement measures. This can render supposedly optimal policies inefficient if the target levels differ, even for identical regions. In short, cost-effective ratios of abatement measures do not retain their cost-effectiveness under any other constraint.

This result has policy relevance when fulfilling the requirements of the European Water Framework Directive. The eventual nutrient reduction targets, based on baseline scenarios and water quality requirements, will be unique for each ba$\sin$. Hence the cost-effectiveness of supplementary measures has to be assessed on an individual basin level, even if there are comparable basins conduct- ing cost-effectiveness analysis. This should be taken into account when coordinating research of the implementation of the directive.

Single basins will have only limited sets of potential measures to reduce agricultural nutrient loads. Hence, in their cost-effectiveness assessments, they shall not provide general nutrient abatement cost functions that cover a large range of constraints. Most probably, their analysis will consist of few alternative measures, from which they choose the lowest cost combination. These kinds of plans will not be cost-effective for other basins, targeting at different levels of abatement. This result is further complicated if other basins have to reduce, say nitrogen instead of phosphorus, or a combination of both.

However, beyond the implications to policy makers, the findings of our paper also raise questions regarding the direction of future research. For instance, what role could national and international research play? In the view of this paper, one of the most central areas would be provision of accurate nutrient abatement cost functions for a large range of abatement levels. With the help of these the individual river basins could, knowing the available abatement measures and their current utilization, plan efficient schemes to reach the basin specific environmental targets. For instance, an example of this kind of reporting is found in Hart and Brady (2002).

The measures could also be simply ranked with respect to the desired phosphorus (nitrogen) abatement level, so that they could be applied gradually while maintaining the cost-effectiveness along the abatement path. In its simplest form, this would provide an order of application which the basins can follow as they tighten their environmental targets.

Our results suggest that the economic instruments for agri-environmental policy might have to be strongly diversified in order to sustain different policies for different basins. The possibilities and costs of diversifying the instruments should be addressed in further studies. Uniform agri-environmental policy is the alternative to diversification. Our paper quantifies the costs of one problem related to uniform policies. Uniform incentives 
throughout identical basins cause similar actions by economic agents. Even though the incentives were designed to yield cost-effective abatement allocations in an average basin, the differences in target levels cause inefficiencies. This holds thus in a deterministic world with identical basins. There are already many studies on diversifying economic instruments, but to our knowledge, not in the context of the WFD. The basin wide approach of WFD, and its strong emphasis on costeffectiveness, face severe difficulties if there are only uniform agri-environmental instruments available.

And finally, other research issues not covered in our paper whose absence was highlighted during its completion include: the effects of combining different measures with respect to partly counter-effective results in phosphorus and nitrogen reduction; the issue of the different phosphorus forms' varying effect on eutrophication ${ }^{22}$. In conclusion, our paper highlights the potentially hazardous shortcomings in inadequately modelling cost-effective policies, which may even reverse their cost-effectiveness. These shortcomings are deserving of further research and would provide, not only a basis for efficient policy making within the WFD's current requirements, but will also provide an invaluable basis for any future calculations of cost-effective abatement measures.

Acknowledgements. Part of this work has been funded by the project: "Benchmark models for the Water Framework Directive" (BMW; contract no: ECVK1-CT2001-00093), by Finnish Cultural Foundation and Kyösti Haataja Foundation. The author wishes to thank Prof. Markku Ollikainen and Dr. Marko Lindroos for their encouragement and comments; Ilona Bärlund, Teija Kirkkala and Kirsti Granlund for fruitful discussions; and two anonymous referees for their thorough and educative comments.

\footnotetext{
${ }^{22}$ Recall that dissolved reactive phosphorus contributes to eutrophication much more strongly than particulate phosphorus, but most of the end-of-pipe kind of measures reduce only particulate phosphorus, and may even increase the loss of dissolved phosphorus.
}

\section{References}

Baumol, W.J. \& Oates, W.E. 1988. The theory of environmental policy. USA: Cambridge University Press. $299 \mathrm{p}$.

Brady, M. 2003. The relative cost-efficiency of arable nitrogen management in Sweden. Ecological Economics 47: $53-70$.

Byström, O. 2000. The replacement value of wetlands in Sweden. Environmental and Resource Economics 16, 4: 347-362.

Dosskey, M.G. 2002. Setting priorities for research on pollution reduction functions of agricultural buffers. Environmental Management 30, 5: 641-650.

Ekholm, P. 1998. Algal-available phosphorus originating from agriculture and municipalities. Monographs of the Boreal Environment Research 11. Tampere: TammerPaino oy. $60 \mathrm{p}$.

Ekholm, P., Turtola, E., Grönroos, J., Seuri, P. \& Ylivainio, K. 2005. Phosphorus loss from different farming systems estimated from soil surface phosphorus balance. Agriculture, Ecosystems and Environment 110: 266278.

Elofsson, K. 1997. Cost effective reductions in the agricultural load of nitrogen to the Baltic Sea. Swedish University of Agricultural Sciences. Dissertations 28. 67 p.

Fleming, R.A. \& Adams, R.M. 1997. The importance of sitespecific information in the design of policies to control pollution. Journal of Environmental Economics and Management 33: 347-358.

Finland's Natural Resources and the Environment 2002. Statistics Finland. Helsinki. 78 p.

Gren, I.-M. 2001. International versus national actions against nitrogen pollution of the Baltic Sea. Environmental and Resource Economics 20, 1: 41-59.

Hart, R. \& Brady, M. 2002. Nitrogen in the Baltic Sea - policy implications of stock effects. Journal of Environmental Management 66: 91-103.

HELCOM 1994. Intergovernmental activities in the framework of the Helsinki Convention 1974-1994. Baltic Sea Environment Proceedings No. 56. 235 p.

Helfand, G.E. \& House, B.W. 1995. Regulating nonpoint source pollution under heterogeneous conditions. American journal of Agricultural Economics 77: 10241032.

Iho, A. 2004. Cost-effective reduction of phosphorus from agriculture: a numerical analysis. Department of Economics and Management, University of Helsinki. Discussion Papers 3. 25 p.

Kuusela, R. \& Savola, A. 2000. Yläneenjoen ja sen sivupurojen kiintoaine- ja ravinnekuormitus 1991-1996. Lounais-Suomen ympäristökeskuksen monistesarja 21. $55 \mathrm{p}$.

Lankoski, J. \& Ollikainen, M. 2003. Agri-environmental externalities: a framework for designing targeted policies. European Review of Agricultural Economics 30, 1: 51-75.

Lichtenberg, E. 2002. Agriculture and the environment. In: Gardner, B. \& Rausser, G.C. (eds.). Handbook of agricultural economics, Vol. 2. Amsterdam, Elsevier. p. $1250-1305$. 
Vol. 14 (2005): 277-292.

Maa- ja metsätalousministeriö 2002. Suojavyöhykkeen perustaminen ja hoito. Maatalouden ympäristötuen erityistuet 2000-2006. $12 \mathrm{p}$.

Maatalouden ympäristöohjelma 1995-1999:n taloudellinen analyysi.Ympäristötukijärjestelmä ja tulevaisuus -tutkimuksen loppuraportti, 1999. MTTL julkaisuja 90. $159 \mathrm{p}$.

McDowell, R.W. \& Sharpley, A.N. 2001. Approximating phosphorus release from soils to surface runoff and subsurface drainage. Journal of Environmental Quality 30: 508-520.

Myyrä, S. \& Pietola, K. 2005. Land improvements under land tenure insecurity. The case of liming in Finland. In: 94th EAAE Seminar. Wye Campus, Imperial College London, 9-10 April 2005. Available on the Internet: http://www.eaae-wye.org.uk/papers/Myyra-Pietola.pdf

Ollikainen, M. \& Honkatukia, J. Towards efficient pollution control in the Baltic Sea: an anatomy of current failure with suggestions for change. Ambio 30, 4: 245-253.

Palva, R., Rankinen, K., Granlund, K., Grönroos, J., Nikander, A. \& Rekolainen, S. 2001. Maatalouden ympäristötuen toimenpiteiden toteutuminen ja vaikutukset vesistökuormitukseen vuosina 1995-1999. Summary: Environmental impacts of agri-environmental support scheme in 1995-1999. Mytvas-projektin loppuraportti. Suomen ympäristö $478.92 \mathrm{p}$.

Pote, D.H., Daniel, T.C., Sharpley, A.N., Moore, P.A., Jr., Edwards, D.R. \& Nichols, D.J. 1996. Relating extractable soil phosphorus to phosphorus losses in runoff. Soil Science Society of America Journal 60: 855-859.

Puustinen, M., Koskiaho, J., Gran, V., Jormola, J., Maijala, T., Mikkola-Roos, M., Puumala, M., Riihimäki, J., Räty, M. \& Sammalkorpi, I. 2001. Maatalouden vesiensuojelukosteikot. Vesikot-projektin loppuraportti. Summary: Constructed wetlands for agricultural loading. Final report of the Vesikot-project. Suomen ympäristö 499. $63 \mathrm{p}$.

Reinhardt, M., Gächter, R., Wehrli, B. \& Muller, B. 2005. Phosphorus retention in small constructed wetlands treating agricultural drainage water. Journal of Environmental Quality 34, 4: 1251-1259.

Saarela, I., Järvi, A., Hakkola, H. \& Rinne, K. 1995. Fosforilannoituksen porraskokeet 1977-1994 Summary: Phosphorus fertilizer rate trials, 1977-1994. Maatalouden tutkimuskeskus, Tiedote 16/95. 94 p. + 14 app.
Saarela, I., Järvi, A., Hakkola, H. \& Rinne, K. 2003. Phosphorus status of diverse soils in Finland as influenced by long-term $P$ fertilisation I. Native and previously applied P at 24 experimental sites. Agricultural and Food Science in Finland 12: 117-132.

Saarela, I. \& Saarela, K. 1999. Ravinteiden saatavuuden ja sijainnin määritys maasta ohutdiffuusiotekniikoilla. Maatalouden tutkimuskeskuksen julkaisuja Sarja A 67. p. 232.

Segerson, K. 1988. Uncertainty and incentives for nonpoint pollution control. Journal of Environmental Economics and Management 15: 87-98.

Sharpley, A.N. 1995. Dependence of runoff phosphorus on extractable soil phosphorus. Journal of Environmental Quality 24: 920-926.

Sharpley, A.N. \& Rekolainen, S. 1997. Phosphorus in agriculture and its environmental implications. In: Tunney, $\mathrm{H}$. et al. (eds.). Phosphorus loss from soil to water. CAB International. p. 1-53.

Suomen Itämeren suojeluohjelma 2002. Summary: Finland's program for the protection of the Baltic Sea, The Finnish government's decision-in-principle. Suomen ympäristö 569. 97 p.

Uusi-Kämppä, J. \& Kilpinen, M. 2000. Suojakaistat ravinnekuormituksen vähentäjänä. Maatalouden tutkimuskeskuksen julkaisuja 83. 49 p.

Vesiensuojelun tavoitteet vuoteen 2005. Summary: Water protection targets to 2005. Suomen ympäristö 226. $82 \mathrm{p}$.

Vought, L.B.-M., Dahl, J., Lauge Pedersen, C. \& Lacoursiere, J.O. 1994. Nutrient retention in Riparian ecotones. Ambio 23, 6: 342-348.

Xepapadeas, A.P. 1995. Observability and choice of instrument mix in the control of externalities. Journal of Public Economics 56: 485-498.

Yli-Halla, M., Hartikainen, H. \& Väätäinen, P. 2002. Depletion of soil phosphorus as assessed by several indicies of phosphorus supplying power. European Journal of Soil Science 53: 431-438.

Ylivainio, K., Esala, M. \& Turtola E. 2002. Luonnonmukaisen ja tavanomaisen viljelyn typpi- ja fosforihuuhtoumat kirjallisuuskatsaus. Summary: Nitrogen leaching and phosphorus loss in organic and conventional farming - literature review. Maa- ja elintarviketalous 12. 74 p. 


\title{
SELOSTUS
}

\section{Maatalouden ravinnekuormituksen vähentämisen kustannustehokkuus}

\author{
Antti Iho \\ Helsingin yliopisto
}

Maatalouden ravinnekuormituksen vähentämiseen on suuria paineita, ja vähennyksiltä edellytetään usein kustannustehokkuutta. Esimerkiksi EU:n vesipuitedirektiivi edellyttää kustannustehokkuustarkastelua niiltä ylimääräisiltä toimenpiteiltä, joita ympäristöllisiin tavoitteisiin pääseminen vuoteen 2015 mennessä edellyttää. Vesiensuojelualueille asetettavat mahdolliset vähennystavoitteet saattavat poiketa toisistaan merkittävästi. Tämä vaikuttaa kustannustehokkuusanalyysien soveltuvuuteen eri alueiden välillä. Tässä tutkimuksessa pyritään esittelemään ja kvantifioimaan näitä vaikutuksia. Ratkaisemme kustannustehokkaan suojeluratkaisun kolmen eri vesiensuojelumenetelmän kesken fosforin vähennyksen eri tavoitetasoille, ja vertailemme suojeluratkaisujen kustannustehokkuutta eri mittakaavassa toteutettuna. Osoitamme, että jopa homogeenisten alueiden kustannustehokkaat suojeluratkaisut riippuvat voimakkaasti vähennysten kokonaistasosta. Näin ollen eri alueet eivät voi suojelussaan toteuttaa kustannustehokkuutta soveltamalla toisten, vaikkakin samankaltaisten, alueiden kustannustehokkaita suojeluratkaisuja omalle alueelleen, mikäli vähennystavoitteet eroavat toisistaan. Tulosten perusteella otamme kantaa kustannustehokkuusanalyysin käyttöön vesipuitedirektiivin yhteydessä. 